\author{
STUDIA POLONIJNE \\ T. 42 LUBLIN 2021 \\ DOI: $\frac{\mathrm{h} \text { htp://doi.org/10.18290/sp21 }}{42.13}$
}

ROBERT ZAPART

\title{
JOINT MILITARY FORCES OF EAST-CENTRAL EUROPE IN THE LIGHT OF SELECTED POLITICAL CONCEPTS OF THE POLISH ÉMIGRÉ MILIEU
}

On the basis of experiences related to the outbreak of the Second World War, projects emerged at various representations of Polish authorities in exile concerning the future creation in the East-Central part of the Old Continent of a regional community free of totalitarianism and capable of conducting an effective security and defence policy on its own. They were heralded by intergovernmental agreements of 1942, the first of which concerned the future confederation of Poland and Czechoslovakia, the other of Yugoslavia and Greece. These constituted, after a possible accession of neighbouring states, the nucleus of a Central-European and a Balkan confederation, respectively. Alternative to the above, non-governmental projects focused on expanding, but also often deepening, forms of regional integration. In this respect, Józef Piłsudski's idea of Intermarium was frequently evoked, which promoted broader cooperation between the states lying between the three seas - the Adriatic, Baltic and Black - aimed at reducing the threat of this part of the continent being dominated by Russia and Germany ${ }^{1}$. Most of the political concepts developed by Poles in exile which promoted integration included postulates to create armed forces in East-Central Europe, which were to secure its international subjectivity in the future. The following deliberations will focus on presenting them and offering their functional analysis from the perspective of selected projects. The examples cited, which are

Dr ROBERT ZAPART - assistant professor in the Department of National and Internal Security at the Institute of Political Science, College of Social Sciences, University of Rzeszów, al. mjr. W. Kopisto 2a, 35-959 Rzeszów, Poland; e-mail: rzapart@ur.edu.pl; ORCID: https://orcid.org/0000-00023590-1189.

${ }^{1}$ P. OKULEwicz, Koncepcja “Międzymorza” jako próba stworzenia strefy bezpieczeństwa między Niemcami a Rosja w okresie przedwojennym, [in:] O nowy ksztalt Europy. XX-wieczne koncepcje federalistyczne w Europie Środkowo-Wschodniej i ich implikacje dla dyskusji o przyszłości Europy, eds. J. Kłoczowski, S. Łukasiewicz, Lublin 2003, pp. 64-73. 
representative of various political ideas, certainly do not exhaust the subject yet they do allow for their general evaluation. Helpful in this respect are the selected research methods, content analysis of sources and the comparative method. The study will be accompanied by the premise that the assumptions of the said projects of joint armed forces were over-optimistic due to the political (in the international and internal dimensions), military, social, economic and cultural problems which could not be resolved at the time and which affected their final success or failure.

\section{BETWEEN GERMANY AND RUSSIA:}

\section{CONCEPTS FOR THE SECURITY POLICY OF THE POLISH AUTHORITIES IN EXILE AFTER THE END OF THE SECOND WORLD WAR}

Regardless of their political orientation, the Polish émigré circles envisaged two variants of post-war political developments. The first involved the continuation, with some adjustments, of the wartime alliance of the superpowers, while the other envisaged ideological disputes and, as a consequence, a military clash ending in the defeat of one of the parties to it. Either of these scenarios entailed different perspectives for Poland and the mission of the country's representatives in exile, although it was the latter scenario involving the defeat of the Soviet empire as part of another global conflict or disintegration as a result of various forms of political and economic pressure - that was optimistically assumed to materialise. The vast majority shared the post-war view of the nationalist leader Tadeusz Bielecki that the rivalry between the existing allies was intensifying and that a hidden war was underway, or at best a 'period of armed peace'2. It was also believed that the old model of European organisation, based on a division into two complementary areas, the industrial West and the agricultural East, would be replaced by a different formula of integration. Efforts were therefore made to build, together with other émigré representatives of the Soviet-subjugated nations of East-Central Europe, a regional integration project that was to be part of a larger plan aimed at stabilising the security of the entire continent. At the same time, it was assumed that this could not be an exclusive club limiting access for other interested states, but the core of a community to be included in the future in the circle of Western European democracies. This

\footnotetext{
${ }^{2} \mathrm{C}$. SKUZA, Bezpieczeństwo zewnętrzne państwa w programach i działaniach polskich polityków (1939-1955), Szczecin 2012, pp. 142-145.
} 
was reflected in 1947 governmental analyses, which indicated that only a close union of the countries of East-Central Europe could guarantee real independence to the medium-sized and smaller nations living there. In these projects, Poland was to play the role of a regional integrator, and - by extension a creator of the future security policy, due to its geographical location and the greatest social and economic potential. The future of the community was outlined on the basis of two solutions. The first of these involved the creation of a federal state, while the other - favoured by the vast majority of émigré circles - involved the establishment of a confederation bringing together the countries concerned within the framework of a looser, but also gradual - as Europe would continue to integrate - cooperation protecting the foundations of their national identities ${ }^{3}$. It was also supported by a poll conducted in 1952 among Polish émigrés by the Kultura magazine ${ }^{4}$. Strategically, the East-Central European Union was to be an intermediate form between states and continental unions on the one hand and a global organisation on the other. The proportional division of the Old Continent into the Western Bloc, Germany, East-Central Europe and Russia (sometimes Scandinavia was also mentioned) was, according to the proponents of such a form of integration, supposed to be conducive to maintaining political balance. Generally speaking, non-associated countries and regional groupings were to become basic units - in relation to the continental association - with similar rights and obligations. At this point, there was also some doubt as to whether a legal distinction could be drawn between the future European Union and the Central European Union. It remains unresolved to this day, although some of the projects that were promoted did not exclude the chances of both entities acting simultaneously within their respective competences. The decisive factor in this respect would be the attitude of unifying Western Europe and the United States towards the regional union and the states remaining outside it ${ }^{5}$.

According to the federalists, who were the most vocal in championing broader and deeper integration, a smaller community (Poland and Czechoslovakia or Poland and the Baltic States), promoted by the government and some of political elites linked to it, would not have the potential to effectively eliminate external threats from Poland's either eastern or western neighbour. Alternative unions, such as the Danube Federation, would recreate the

\footnotetext{
${ }^{3}$ P. WANDYCZ, L. FRENDL, Zjednoczona Europa, teoria i praktyka, Londyn 1965, p. 44; R. ZAPART, Władze RP na uchodźstwie o projekcie polsko-czechostowackiej integracji w latach osiemdziesiatych XX wieku, "Studia Polonijne" 35(2014), p. 48.

${ }^{4}$ J. MieroszewsKi, Opinia emigracji, "Kultura", 1953, no. 4(66), pp. 4-5.

${ }^{5}$ P. MACHCEWICZ, Emigracja w polityce międzynarodowej, Warszawa 1999, p. 40.
} 
situation threatening Poland at the time of the Austro-Hungarian Empire remaining under German influence. On the other hand, within this slightly larger Central European community, the possibility of closer cooperation between certain states was accepted, for example Poland and Lithuania, Hungary and Romania, or the Czech Republic and Slovakia, which was to help resolve disputes between them on the road to integration ${ }^{6}$. This was reflected in attempts to rebuild the earlier Polish-Czechoslovak agreement, which was to be extended to include other states. In the broadest sense, a confederation or federation would unite the peoples of Intermarium, i.e.: Albanians, Belarusians, Bulgarians, Croats, Czechs, Estonians, Greeks, Hungarians, Latvians, Lithuanians, Poles, Romanians, Serbs, Slovaks, Slovenes, and Ukrainians. The condition for success was to be the prior disintegration of the Soviet Union by including Lithuania, Latvia and Estonia in the projected union because of their importance for the control of the Baltic Sea. The USSR was also to be pushed beyond the Carpathian Mountains as its control over the nations of Eastern Europe was conducive to maintaining its hegemony ${ }^{7}$. All of the above concepts were based on the conviction that the best way to secure the independence of Poland and other countries in the region would be to integrate them in the areas most important for maintaining their independence, in particular common foreign, security and defence as well as economic policies $^{8}$. The real problem that Polish diplomats had to face was to agree on a uniform plan in their own political circles, and then with other representatives of the Soviet-subjugated nations of East-Central Europe. It often turned out that each national group had contradictory comments to make, including those concerning the future borders and political system. In general, the willingness of the other partners to cooperate was overestimated, and the differences of opinion, pronounced and difficult to overcome without full participation of the peoples remaining in their own states, not sufficiently appreciated. However, for exiled Poles and representatives of other Sovietcontrolled nations of East-Central Europe, the postulate of uniting many millions of its inhabitants seemed an interesting practical solution to eliminate the threat from Germany and Russia to the whole of Europe ${ }^{9}$. There were,

\footnotetext{
${ }^{6}$ Archive of Independence Museum, sign. 108, J. Kuncewicz, Zadania i pozycja Polski w uktadzie powojennym, Collection of Documents Zygmunt Berezowski, p. 139.

${ }^{7}$ P. MACHCEWICZ, Emigracja..., pp. 39-40.

${ }^{8}$ E. RACZYŃSKI, Europeizm czy regionalizm, "Kultura" 1954, no. 5, pp. 100-107.

${ }^{9}$ More about: M.S. WOLAŃSKI, Europa Środkowo-Wschodnia w myśli politycznej emigracji polskiej w latach 1945-1975, Wrocław 1996; J. ŁAPTOS, Europa marzycieli. Wizje i projekty integracyjne środkowoeuropejskiej emigracji politycznej 1940-1956, Kraków 2012.
} 
however, opposing voices pointing out the excessive emotionality of the parties, which was detrimental to a substantive discussion on the shape of postwar Europe. Cold calculation was expected, and post-war wounds were to be healed with 'the most tried and tested means, rather than throwing oneself into risky experiments ${ }^{\prime}$.

\section{THE MACHIAVELLIAN PARADIGM ON THE ROLE OF THE NATIONAL ARMY VERSUS POLITICAL AND MILITARY REALITY}

In signalling the necessity of adopting a common security and defence policy for East-Central Europe, attempts were made to overcome the conviction, based on Machiavelli's paradigm, that the role of the national army was dominant in protecting state sovereignty ${ }^{11}$. This was to be achieved, inter alia, by shifting the burden of discussion in this area to the international level and by seeking out communities in the immediate neighbourhood similarly war-affected by individual disasters, as well as ones sharing the same opinion on identical threats and expecting effective protection of fundamental values as a guarantee of their subjective existence. At the same time, it was pointed out that the potential of states acting independently in their own defence was insufficient. Building a community of mutually responsible actors capable of effectively eliminating or significantly reducing existing disputes in mutual relations was a priority task for the continuing success of all integration projects, each of which entailed the partial relinquishment of certain attributes of sovereignty to a jointly established entity. The perception of needs in this area, and consequently the shape of the postulated systemic relations, was influenced by ideological diversity, not only within each diaspora, but also between them. Despite serious differences concerning the notion of integration, most of them accepted the need to create joint armed forces with the potential to ensure independent defence against threats from the East or West. Among the related issues, the following came to the fore:

a) scope and form of integration of the states of the region, competences of the joint entity's leadership in the management of defence matters, as well as the presence of its representatives in international security organisations

\footnotetext{
10 M. Szerer, Federacje a przyszłość Polski, Londyn 1942, p. 28.

${ }^{11}$ M. MANELI, Machiavelli, Warszawa 1968, p. 97.
} 
b) methods of establishing joint armed forces and their cooperation with national armies

c) methods of assembling command and general staff subordinated to the political authorities of the community

d) language used in military units,

e) system of garrison deployment

f) rules of supplying joint armed forces with weapons, ammunition and food ${ }^{12}$.

In principle, there was a consensus on basing joint defence mechanisms on the commitment of each party to the agreement to provide unconditional assistance in the event of an external threat to any of them. Such solutions limited, for example with regard to the military matters considered in this article, the possibilities of subjective interpretation of the scale of threats and the scope of possible assistance to the state under attack. Unlike Article 5 of the North Atlantic Treaty, which requires the supporting Parties to take such measures as are deemed 'necessary, including the use of armed force' ${ }^{13}$, the supporting Parties were free to determine for themselves the scope of assistance to be provided to the attacked state. They could therefore independently determine the scope of support for all other signatories. The postulate of unconditionality could certainly strengthen the political, social and cultural bonds of a regional agreement, and also affect the perception of such a community by a potential adversary, which had to assess the risk of success of its own actions in terms of the whole, rather than the individual states which it might target. The potential of the postulated security system of East-Central Europe was differentiated by the size of the community, the level of integration, and also the strength of the desired alliance ties complementing it.

\section{3. (CON)FEDERATION ARMED FORCES}

It was estimated that the potential of the entire Central European exiled community would allow for the deployment of full-time units supporting the West in the first phase of a potential conflict, with the number of officers and soldiers ranging from 200,000 to nearly 300,000 according to various

12 C.C., Od idei do rzeczywistości Intermarium, "Biuletyn Informacyjny Intermarium", publ. Central European Federal Club, Roma 1947, no. 5, pp. 15-16.

13 The North Atlantic Treaty, Washington D.C., 4 April 1949, Journal of Laws [Dz.U.] 2000 No. 87, item 970. 
estimates, the vast majority of them Poles (around 230,000) ${ }^{14}$. After the Soviets withdrew from East-Central Europe, they were to be reinforced by positively vetted lower commanders and soldiers from national armies previously subordinated to the Warsaw Pact command. In the case of the joint armed forces of Poland (its mobilisation potential was put at 800,000 conscripts), Czechoslovakia, Hungary, Bulgaria and Romania alone, this could have resulted in a total of 1.5-1.8 million officers and soldiers of all types of troops in the early 1950s. By comparison, the Soviet Union had at that time, without the support of satellite states, an army more than twice as large, and with them of about 6.2 million, backed up by its own nuclear potential ${ }^{15}$.

Already during the Second World War, the authorities of the Polish Republic in exile promoted the project of a Polish-Czechoslovak confederation, one of the aims of which was a common security and defence policy. It was to be implemented on the basis of jointly appointed bodies, including the President, who would exercise supreme authority over the armed forces of the Union. He was to be appointed for a one-year term of office from among representatives to the Supreme Council of the Union elected by the national parliaments. His influence on matters of the confederation's security and defence policy was manifested through his participation in decisions on war and peace - together with the other members of the aforementioned Council and the Council of Secretaries acting as ministers in matters specified in the community treaty - and the appointment or dismissal of the Union's Prime Minister and, at his request, the Secretaries of State, among whom was also the Union's Defence Secretary. In addition, at the request of the latter, the President was to appoint the Chief of the Union's General Staff and generals. The institutional foundation of the security policy was supplemented by an executive structure based for the most part on the Union's Defence Secretary. It was within his competence to direct the confederation's preparations for defence and to administer its budget for the implementation of the war plans developed by the Union's Defence Staff. In addition, the Secretary, at the request of the Chief of the Union's Defence Staff, was to determine the peacetime deployment of the military units of the states belonging to the Union

${ }^{14}$ P. MACHCEWICZ, Emigracja ..., pp. 75, 81; Z. WoźNICZKA, Trzecia wojna światowa $w$ oczekiwaniach emigracji i podziemia $w$ kraju $w$ latach 1944-1953, Katowice 1999, pp. 221-244; A. ZAĆMIŃSKI, Emigracja polska w Wielkiej Brytanii wobec możliwości wybuchu III wojny światowej 1945-1954, Bydgoszcz 2003, pp. 162, 169.

${ }^{15}$ L. PAwlikowicz, R. ZAPART, Znaczenie Europy Środkowo-Wschodniej w zimnowojennych koncepcjach polskiego wychodźstwa na tle potencjatu wielkich mocarstw, "Studia Polonijne" 41(2020), pp. 307-308. 
and submit to the President the general and admiral appointments consulted with him $^{16}$. The role of the Chief of the Union's Defence Staff was primarily associated with the preparation of its armed forces for war, as well as fulfilling the position of Commander-in-Chief in the event of its outbreak. His competences in this respect did not differ from those which had previously applied in the case of the 1935 Polish Constitution, and thus included directing war operations, conferring decorations, or dismissing and appointing commanders. The positions differed in their subordination to the highest civilian authorities. In the former case, it was the President of the Republic of Poland, while in the latter, which was related to commanding the joint armed forces of the Union, the Council of Secretaries headed by the Prime Minis$\operatorname{ter}^{17}$. The success of the above project of integration of Poland and Czechoslovakia, especially in the security and defence policy, depended on real, rather than declared, cooperation of its signatories, as well as the future reaction of their neighbours to the new entity in international relations. The former issue in particular could raise certain doubts as to achieving the desired effectiveness if the confederation were to comprise a significantly larger number of states than originally projected, a matter which was repeatedly discussed in émigré opinion-forming circles ${ }^{18}$. In the latter case, it would be difficult to be optimistic in the context of a potential discussion concerning the deployment of joint military units in the event of the Union's enlargement to include countries which lacked significant military added value for the Union and at the same time perceived the scale and type of threats differently. Similar doubts would apply to their geographical location and to the perception of individual societies not necessarily aware of the purpose of establishing defence alliances. Certainly, the command of the joint, but not only Polish-Czechoslovak, armed forces would be problematic, too, because if the number of regionally integrating states were to increase, the problems would deepen in terms of the compatibility of military equipment, the unification of training, internal communications and the use of national symbols and colours.

There was a general consensus in the circles linked to federal-minded clubs which promoted broader and deeper cooperation between the states of

\footnotetext{
${ }^{16}$ Zasady Aktu Konstytucyjnego Związku Polski i Czechosłowacji in: T. KISIELEwsKi, Federacja środkowo-europejska. Pertraktacje polsko-czechostowackie 1939-1943, Warszawa 1991, pp. 259-263 (appx.).

${ }^{17}$ Ibidem, p. 264.

${ }^{18}$ S. ŁUKASIEWICZ, Dyskusje o wspótpracy polsko-czechosłowackiej po 1948 roku, [in:] O nowy ksztalt Europy..., p. 235.
} 
Intermarium as regards the foundations of a future regional security policy. It included the aforementioned principle of common defence, based on the obligation of each member state to provide assistance should one or more of them come under attack. This also entailed the necessity to establish a single management dealing with defence matters ${ }^{19}$. It differed from the previously mentioned Polish-Czechoslovak concept by being a deeper form of integration and more open to other actors in the Intermarium area, and consequently by having a vision for joint armed forces. The project envisaged that the integrating states would transfer a large part of their sovereignty to the authorities of the Central European Federation, including, apart from external representation, the economy and matters of cooperation between societies in the fields of culture and healthcare, foreign policy as well as security and defence. The last mentioned was to be ensured by its joint armed forces based on decision-making unity and continuity of the supreme authorities of the community. A federal government formed by the member states was to be responsible for the implementation of the security and defence policy and for any war that might arise. No state could hold a majority in it, and the presence of a minimum of one representative per country was the rule ${ }^{20}$. The entire defence of the Union, including the coordination of all federal institutions, was entrusted to the Chancellor at the head of a five-department government (foreign policy, armed forces, economy, treasury, and social affairs). His advisory body was to be the Federal Defence Council with representatives of all members of the community sitting on it. Responsibility for the material preparation and mobilisation of the Union's armed forces, as well as the coordination of work with other ministries in peacetime and wartime, rested on the shoulders of the Secretary of State in charge of one of the aforementioned ministries. Special matters for individual weapons of the federal and national armed forces were entrusted to the Community Under-Secretaries of State and the Ministers for Military Affairs of the member states ${ }^{21}$. The Armed Forces of the Union were to comprise: the Community shock (land) army, air force, navy and air defence, as well as the national armies of each state supplementing the Union's potential. It was postulated that their supreme head would be the Head of the Federation, while the second-incommand and permanent head would be the Chancellor. Unfortunately, there

\footnotetext{
${ }^{19}$ Karta Wolnego Międzymorza, publ. Central European Federal Club, Roma 1946, p. 12.

${ }^{20}$ Archive of Jagiellonian University, sign. 11840, Tezy, p. 331.

${ }^{21}$ Ibidem, p. 337. More about: R. ZAPART, Konstytucja Federacji Środkowo-Europejskiej jako wyraz integracyjnego idealizmu $w$ budowie systemu regionalnego bezpieczeństwa $w$ myśli politycznej polskiego wychodźstwa w XX wieku, "Studia Polonijne" 39(2018), pp. 251-279.
} 
was a major gap in the draft as it did not specify the manner in which the President of the Union would be elected, leaving these matters to the first constitutional assembly, the Congress (the Chamber of Deputies elected by universal suffrage under five-point electoral law) and the Federal Senate (the Chamber of Nations consisting of senators elected in equal numbers from each state of the Union), to which a number of prerogatives fundamental to security and defence policy were ascribed, to name but a few: the determination of war and peace at the request of the federal government and under the countersignature of the Council of State (the supreme body of the Union consisting of the Presidents of the Congress and the Federal Senate and the Speakers of the lower and higher parliamentary chambers of each member state of the community), and the appointment and dismissal of the Chancellor, the Secretaries of State, and at the request of the government, under the countersignature of the said Council, the Chief of Staff of the Union ${ }^{22}$. The entire armed forces of the community were under the command of the Union's Chief of Staff in time of peace and war. In case of the former, he was to report directly to the Secretary of State for the Armed Forces of the Union, and in case of the latter, to the Chancellor ${ }^{23}$. An integral part of the security and defence system was to be complementary raw material and industrial resources of individual states, and in particular a jointly developed common arms industry, relatively good railway connections, community borders based on natural barriers, as well as the demographic potential of the Intermarium area with a population of around 160 million, from which military forces matching the size of the enemy could be formed. All matters not covered by federal legislation and the competences of the Union's authorities were to remain the domain of the member states. However, the problem of national symbols and colours was not resolved within the framework of such federal projects, although it was proposed that a system of communication be developed in the future armed forces of the Intermarium area (it was suggested that national languages be preserved, but English be used in command structures) and that their oath of allegiance be taken to Europe and their respective countries ${ }^{24}$. This approach clearly indicated the directions of the future integration of the East-Central European armed forces of with those of Western states.

\footnotetext{
${ }^{22}$ Archive of Jagiellonian University, sign. 11840, Tezy, p. 330.

${ }^{23}$ Ibidem, p. 338.

${ }^{24}$ P. WANDYCZ, Międzynarodowe organizacje ruchu federalnego, [in:] O jedność Europy. Antologia polskiej XX-wiecznej myśli europejskiej, ed. S. Łukasiewicz, Warszawa 2015, p. 104.
} 
The concept of the joint armed forces of East-Central Europe, based on the ideas of the aforementioned federalism, was presented by the politician and publicist Juliusz Mieroszewski. The starting point for his considerations was the abandonment, in the era of nuclear weapons possessed by two ideologically opposed political blocs, of projects for the integration of small and medium-sized states in the region, which in any case, in the event of the success of the federation plans, would remain defenceless, and therefore only illusorily sovereign. In his view, it was more important to establish a Central European brigade, representing all the countries from behind the Iron Curtain, as part of the Western units ${ }^{25}$. The above approach differed from the others as regards the notion of rebuilding the national army, support for which by Western states he regarded as unrealistic. Similar projects, but from a different political perspective, were put forward by Zygmunt Czarnecki, who proposed the creation of a Foreign Legion composed exclusively of Poles, as a brigade union within a British unit or as an operationally independent one ${ }^{26}$.

From the perspective of the international relations of the time, however, none of the mentioned concepts of a common security and defence policy could have succeeded, although the émigré circles made attempts to change the attitude of Western countries to their proposals. Only a series of parachute and staff training courses was successfully implemented as part of cooperation with certain NATO states.

The constructive anticipation of the desired developments in international relations became a part of the mission of exiled Poles, on the basis of which the foundations of a future common security and defence policy for EastCentral Europe were laid, even if the region did not really have the necessary political, economic, military and social potential. The very discussion on the permissible limitations of the foundations of sovereignty of the states forming the regional community as well as the building of a new model of cooperation on the basis of various politically acceptable forms may have aroused both curiosity and concern of actors interested in the lack of independence of this part of the Old Continent. However, the abovementioned

\footnotetext{
${ }^{25}$ J. MieroszeWSKI, O międzynarodowa brygade europejska, "Kultura” 1951, no. 11, pp. 78-81.

${ }^{26}$ A. ZAĆMIŃSKI, Emigracja polska w Wielkiej Brytanii..., pp. 158; R. ZAPART, Polska w środkowoeuropejskich koncepcjach Zygmunta Czarneckiego. Emigracyjna myśl polityczna okresu "zimnej wojny", "Studia Polonijne" 33(2012), pp. 99-116.
} 
projects, and not only these, for joint armed forces of a group of EastCentral European states were doomed to failure from the outset, regardless of the value of the concepts presented to the public or the abandonment of the earlier condition of recognising the international subjectivity of the Polish authorities in exile. The policy of Western states in the second half of the 20 th century was determined by the American paradigms that did not envisage making use of the potential of the émigré circles in the creation of NATO. Although the Polish authorities in exile maintained, practically until the end of their mission, earlier proposals of creating a joint forces component, mainly on the basis of the abovementioned Polish-Czechoslovak agreement, they were not used due to a different model of integration and security policies adopted in Europe. It is open to debate whether, in the event of a partial success of any of these integration projects, a smaller or larger community would be strong enough to effectively deter an aggressor with a nuclear capability. It is possible that it would only remain an interesting partner for other entities close to it in terms of development and culture, supplementing deficits in their assets. This does not mean, however, that the concepts of building joint armed forces in our part of the continent developed by émigrés are devoid of cognitive value because in the case of considering alternatives or supplements to the currently pursued security policy based on the North Atlantic Alliance they may constitute a certain contribution to the discussion about the future of East-Central Europe.

\section{BIBLIOGRAPHY}

Archive of Jagiellonian University, sign. 11840, The European Union as a federation: a constitutional analysis.

Archive of Independence Museum, sign. 108, J. Kuncewicz, Zadania i pozycja Polski w układzie powojennym, Collection of Documents Zygmunt Berezowski.

C.C., Od idei do rzeczywistości Intermarium, "Biuletyn Informacyjny Intermarium”, publ. Central European Federal Club, Roma 1947, no. 5.

Karta Wolnego Międzymorza, publ. Central European Federal Club, Roma 1946.

KISIELEWSKI T., Federacja środkowo-europejska. Pertraktacje polsko-czechosłowackie 1939-1943, Warszawa: Ludowa Spółdzielnia Wydawnicza 1991.

ŁAPTOS J., Europa marzycieli. Wizje i projekty integracyjne środkowoeuropejskiej emigracji politycznej 1940-1956, Kraków: AP 2012.

ŁUKASIEWICZ S., Dyskusje o współpracy polsko-czechosłowackiej po 1948 roku, [in:] O nowy kształt Europy. XX-wieczne koncepcje federalistyczne w Europie Środkowo-Wschodniej i ich implikacje dla dyskusji o przyszłości Europy, eds. J. Kłoczowski, S. Łukasiewicz, Lublin: Instytut Europy Środkowo-Wschodniej 2003. 
MACHCEWICZ P., Emigracja w polityce międzynarodowej, Warszawa: Biblioteka WIĘZI 1999.

Maneli M., Machiavelli, Warszawa: Wiedza Powszechna 1968.

MieroszewSKi J., Opinia emigracji, “Kultura” 1953, no. 4(66).

MieroszewsKi J., O międzynarodową brygadę europejską, "Kultura” 1951, no. 11.

OKULEwICZ P., Koncepcja "Międzymorza” jako próba stworzenia strefy bezpieczeństwa między Niemcami a Rosją w okresie przedwojennym, [in:] O nowy kształt Europy. XX-wieczne koncepcje federalistyczne w Europie Środkowo-Wschodniej i ich implikacje dla dyskusji o przyszłości Europy, eds. J. Kłoczowski, S. Łukasiewicz, Lublin: Instytut Europy ŚrodkowoWschodniej 2003.

PAWLikowicz L., ZaPART R., Znaczenie Europy Środkowo-Wschodniej w zimnowojennych koncepcjach polskiego wychodźstwa na tle potencjału wielkich mocarstw, "Studia Polonijne" 41 (2020), pp. 299-318.

RACZYŃSKI E., Europeizm czy regionalizm, “Kultura” 1954, no. 5.

SKUZA C., Bezpieczeństwo zewnętrzne państwa w programach i działaniach polskich polityków (1939-1955), Szczecin: Wydawnictwo USz 2012.

Szerer M., Federacje a przyszłość Polski, Londyn: P.S. King and Staples 1942.

The North Atlantic Treaty, Washington D.C., 4 April 1949, Journal of Laws [Dz.U.] 2000, No. 87, item 970

WANDYCZ P., Międzynarodowe organizacje ruchu federalnego, [in:] O jedność Europy. Antologia polskiej XX-wiecznej myśli europejskiej, ed. S. Łukasiewicz, Warszawa: Biblioteka Jedności Europejskiej 2015.

WAndycz P., Frendl L., Zjednoczona Europa, teoria i praktyka, Londyn: Polonia Book Fund 1965.

WOLAŃSKI M.S., Europa Środkowo-Wschodnia w myśli politycznej emigracji polskiej w latach 1945-1975, Wrocław: Wydawnictwo Uniwersytetu Wrocławskiego 1996.

WoźNICZKa Z., Trzecia wojna światowa w oczekiwaniach emigracji i podziemia w kraju w latach 1944-1953, Katowice: Wydawnictwo Uniwersytetu Śląskiego1999.

ZAĆMIŃSKI A., Emigracja polska w Wielkiej Brytanii wobec możliwości wybuchu III wojny światowej 1945-1954, Bydgoszcz: Wydawnictwo Akademii Bydgoskiej im. Kazimierza Wielkiego 2003.

ZAPART R., Polska w środkowoeuropejskich koncepcjach Zygmunta Czarneckiego. Emigracyjna myśl polityczna okresu "zimnej wojny", "Studia Polonijne" 33(2012), pp. 99-116.

ZAPART R., Władze RP na Uchodźstwie o projekcie polsko-czechosłowackiej integracji w latach osiemdziesiątych XX wieku, "Studia Polonijne" 35(2014), pp. 45-66.

ZAPART R., Konstytucja Federacji Środkowo-Europejskiej jako wyraz integracyjnego idealizmu w budowie systemu regionalnego bezpieczeństwa w myśli politycznej polskiego wychodźstwa w XX wieku, "Studia Polonijne" 39(2018), pp. 265-297. 
JOINT MILITARY FORCES OF EAST-CENTRAL EUROPE IN THE LIGHT OF SELECTED POLITICAL CONCEPTS OF THE POLISH ÉMIGRÉ MILIEU

\author{
Summary
}

This article attempts to analyse the creation of common armed forces in East-Central Europe on the basis of selected integration concepts of the Polish émigré circles. They considered the notion of consolidating the potentials of countries sharing similar historical experiences as well as a sense of being threatened and protecting similar fundamental values to be part of a larger process of providing the Old Continent with guarantees of security and stable development. From the perspective of international relations at that time, however, none of the concepts of a common security and defence policy could have achieved success, although it could have been considered as one of the alternatives for the development of the process of continental integration, especially if it had been linked to the replenishment of the deficient assets in the potentials of other actors of international relations close to East-Central Europe in terms of development and culture.

Keywords: East-Central Europe; security; armed forces; politics; emigre milieu; emigration; integration

\title{
WSPÓLNE SIŁY ZBROJNE EUROPY ŚRODKOWO-WSCHODNIEJ NA BAZIE WYBRANYCH KONCEPCJI POLITYCZNYCH POLSKIEJ EMIGRACJI
}

\section{Streszczenie}

W artykule podjęto próbę analizy koncepcji utworzenia wspólnych sił zbrojnych Europy Środkowo-Wschodniej na bazie wybranych idei integracyjnych polskiej emigracji. Idea konsolidacji potencjałów podobnie doświadczonych historycznie państw, podzielających poczucie zagrożenia, a także chroniących zbliżone fundamentalne wartości, stanowiła według tej ostatniej część większego procesu zapewnienia Staremu Kontynentowi gwarancji bezpieczeństwa i stabilnego rozwoju. $\mathrm{Z}$ perspektywy ówczesnych stosunków międzynarodowych żadna jednak z koncepcji wspólnej polityki bezpieczeństwa i obrony nie mogła uzyskać powodzenia, aczkolwiek mogłaby być rozważana jako jedna $\mathrm{z}$ alternatyw dla rozwoju procesu kontynentalnej integracji, w szczególności, gdyby została powiązana z uzupełnieniem deficytowych aktywów w potencjałach innych bliskich cywilizacyjnie Europie Środkowo-Wschodniej podmiotów stosunków międzynarodowych.

Słowa kluczowe: Europa Środkowo-Wschodnia; bezpieczeństwo; siły zbrojny; polityka; przymusowe wychodźstwo; emigracja; integracja 